\title{
The Philosophy and Approach on which the PROFILES Project is Based
}

JACK HOLBROOK ${ }^{\star 1}$ AND MiIA RANNIKMÄE ${ }^{2}$

$\approx$ This article sets out to describe the PROFILES project, an European Commission $\mathrm{FP}_{7}$ science and society project, addresses problems and issues in science education by guiding teachers to embrace a range of teaching factors, such as a context-based approach, motivational constructivist learning; student centred inquiry teaching; enhancing cognitive conceptualisation, and including socio-scientific decision making. The PROFILES project bases the teaching on a theoretically derived, 3 stage model, which is supported through carefully designed PROFILES modules, providing for both the students and the teacher. The major focus of the project is promoting more relevant school science education at the secondary level (grade 7 and above) by guiding teachers to gain ownership of the PROFILES philosophy and approach.

Keywords: PROFILES, Student motivation, Relevance, 3 stage model, Inquiry learning, Socio-scientific context 


\section{Filozofija in pristop, na katerem temelji projekt PROFILES}

JACK Holbrook ${ }^{\star}$ IN MiIA RANNIKMÄE

$\propto$ Prispevek opredeli projekt PROFILES. To je projekt o naravoslovju in družbi, ki se izvaja v okviru Evropske komisije (FP 7). Njegov namen je premostiti probleme $\mathrm{v}$ naravoslovnem izobraževanju z izobraževanjem učiteljev na različnih področjih, kot so: uporabljanje novega pristopa poučevanja, ki temelji na vsebinah, ki so učencem znane, promoviranje motivacijsko-konstruktivističnega učenja; učenje $\mathrm{z}$ raziskovanjem, pri katerem je v ospredju učenec; izboljšanje razumevanja pojmov in vključevanje odločanja v okviru socionaravoslovnega konteksta. Projekt osnuje poučevanje na tristopenjskem teoretično izpeljanem modelu, ki je za učence in učitelje podprt s skrbno oblikovanimi moduli PROFILES. Glavni cilj projekta je promoviranje pomembnosti naravoslovnega izobraževanja v šolah v višjih razredih (od 7. razreda naprej), in sicer prek tega, da učitelji prevzamejo oz. trajno ponotranjijo filozofijo PROFILES in pristop poučevanja naravoslovja.

Ključne besede: PROFILES, motiviranje učencev, pomembnost, tristopenjski model, učenje $\mathrm{z}$ raziskovanjem, socionaravoslovni kontekst 


\section{Introduction}

I do not believe, after more than 30 years in science education and educational research that we are going to succeed where past generations have failed, unless we make major and fundamental changes in our approach to science education. (J. Lemke, 2005).

A major concern in Europe is the issue of students not taking up science and technology related careers (EC, 2004), which is blamed, at least in part, on the abstractness, boring disposition and non-relevance of science being taught in schools (Osborne, Simons, \& Collins, 2003). In fact, an underlying guiding factor is a European Report (2007) which focuses on the lack of student interest in science education, especially in the adolescent years and suggests that inquiry-based science education (IBSE) is an important component to include in school science education. This EC 2007 publication provides the base for PROFILES (Professional Reflection Oriented Focus Inquiry-based Learning and Education through Science).

Change in school science has traditionally been slow, whereas the pace of scientific and technological development within the society is great, so much so that there is a danger that the changing world is making the relevance of science education even more suspect. This is not only in terms of content and its related conceptual understanding, but also in its approach to developments, its changing field of operation and the changing skills demanded of the teacher. Focusing on learning relevant science for life (for the home, the workplace and interactions in the community), and embrace scientific or technologically related careers, is seen as a key change, not least by a high level commission commenting in an European Commission report entitled Europe needs more scientists (EC, 2004).

Research in a science education context has endorsed the lack of relevance and the out-of-touch science education for today's world and has shown:

a) science subjects are not popular among students and less students are thinking about careers in science and further study in science related areas (Teppo \& Rannikmäe, 2008; EC, 2004);

b) science Is not relevant for students as taught in schools. Students do not see science useful for their lives and future developments (Osborne \& Collins, 2001; Holbrook, 1998; NRC, 2010; Froiland \& Oros, 2013);

c) science content is static in nature, overloaded with facts and theories taken from the past (Rannikmäe, 2001). These bear little relationship with everyday needs; 
d) student perceive school science as dominated by content with too much repetition and too little challenge (Osborne \& Collins, 2001; Sjoberg, 2001; Griffin, Care, \& McGaw, 2012);

e) science education is isolated from the values components of education. Science education tends to be portrayed as values free, yet at the same time, the community needs increasingly to address moral and ethical issues and related problems (Anderson et al., 1992; Holbrook, 1992);

f) teaching lacks attention to higher order learning among students, limiting development of problem-solving and decision-making skills among school graduates (Zoller, 1993; Feinstein, 2010; Choi et al., 2011).

It seems there is a need to rethink the rationale for teaching science in schools, the context in which it is put forward and the manner in which teachers are supported professionally. Essential to this is reflecting on the meaning of "science education." Also essential is reflecting on the relationship of science, if any, to other subjects in the school curriculum and the operationalisation of science teaching to enhance its relevance for a changing world. The PROFILES project strives to promote such thinking and reflections.

\section{Why teach science?}

In reflecting on the place of science teaching in school, an important consideration is that the purpose of teaching science subjects in schools cannot be divorced from the goals of teaching in any subject and hence from the goals of education as a whole (Sjöström, 2011). Of course, the content, laws and theories are very specific to the subject, but the purpose of acquiring these, or why one set of particular set of content, laws and theories, as opposed to another, is put forward, is based on the underlying educational attributes to be developed. For example, should a capability to participate in decision making be very much intended, this value needs to be included in the education system and hence feature in science teaching. In the science teaching case, it can enabling citizens to make informed decisions, drawing on their science learning and to be able to apply this in tackling community issues (Hofstein, Eilks, \& Bybee, 2011). This paints a far different type of a science course than the content, topic driven, science concepts approach which has been familiar to many science teachers (Fernandez, Holbrook, Mamlok-Naaman, \& Coll, 2013).

Rapid changes in the world-including technological advancement, scientific innovation, increased globalization, shifting workforce demands and pressures of economic competitiveness-are redefining the broad skill set that 
students need to be adequately prepared to participate in, and contribute to, today's society (Levy \& Murnane, 2005). The general trend in European countries is towards a knowledge-based society, moving away from a workforce which is manufacturing based and thus drawing attention to the need for research into ways to reorient science and technology education into more conceptual and creative technological approaches that are innovative in their design. In fact, it is suggested there are four separate developmental components to which education and hence science teaching need to embrace or reject. These have been identified (Turner, 2008; Tytler, 2007) as (a) enhancing democratic development, (b) supporting economic development, (c) promoting skills development, and (d) the need for cultural development (Fernandez et al., 2013).

PROFILES subscribes to the inclusion of all these developmental components as integral to science education and thus puts forward the following objectives offering innovative scientific learning opportunities for pre- and inservice teachers:

- $\quad$ Establishing close cooperation and networking of the consortium with stakeholders (seen as going beyond teachers and include educationalists, scientists, researchers, employers).

- $\quad$ Providing teacher professional development in innovative teaching approaches based on teacher needs, especially associated with: student intrinsic motivation; scientific literacy; socio-scientific, context-based teaching; inquiry-based teaching and learning; a student-centred, education-through-science approach; classroom environment; interdisciplinary and cross-cutting learning; self-reflection.

- $\quad$ Developing stronger teacher professionalization by enhancing teacher self-efficacy in innovative teaching using PROFILES modules (based on the innovative teaching approaches).

- Convince teachers that the methods they have studied and tried in the training can and will strongly improve the quality of their own science teaching and thus guide teachers to provide evidence of ownership of the PROFILES approach and philosophy.

- $\quad$ Disseminating the PROFILES ideas.

\section{The Scientific and Technological Literacy element}

It is little wonder therefore that PROFILES focuses attention on clarifying the purpose of science and technology education in the $21^{\text {st }}$ century. A common clarification, expressed in school curricula, is to subsume all the intended purposes into one expression, namely - promoting scientific and technological 
literacy (STL). Alas, many definitions of STL have been developed and the actual intentions of schooling and science education, linked to STL, remain unclear. The trend for STL is associated with a wide meaning, going beyond science content and encompassing societal and workforce concerns. The science concentrates on a few big scientific ideas, rather than stressing a range of disconnected content informational knowledge. While Roberts (2007) identified two camps in defining scientific literacy - the science content emphasis orientation and the science in society focus, others e.g. Holbrook and Rannikmäe (2009) put forward definitions which encompass the creative use of evidence-based knowledge and skills, while recognising also the need for acquiring personal and social attributes. PROFILES recognizes these trends and thus strives to promote STL in its wider vision.

\section{Education through Science}

Many teachers think in terms of science education as, 'science through education' (Holbrook \& Rannikmäe, 2007). This is very much the traditional, or the syllabus, content-component approach to the learning. The learning of the subject is taken as the overriding, and maybe the only, focus. Other aspects, which can play an important role in student motivation are ignored, or heavily downplayed. But whatever the intentions for science education, motivation cannot be ignored and needs to be appreciated as a major factor in science learning (Ryan \& Deci, 2000).

An alternative approach, referred to as the 'education through science' approach (Holbrook, 2010; Holbrook \& Rannikmäe, 2007) is by first stimulating student motivation, so that students are inspired to want to gain education through the teaching. This direction for science education encompasses:

- cognitive learning;

- $\quad$ appreciation of the subject (the nature of science );

- the development of the person to be capable of functioning in a meaningful and responsible manner;

- $\quad$ the development of the person, especially in terms of social values (Holbrook \& Rannikmäe, 2007).

Education through science is thus about intellectual or cognitive development plus personal development plus social development.

Through an 'education through science,' focus the stress is on educational learning to be acquired through science lessons. Education is thus the focus and science is the vehicle (that which is providing the content). 


\section{What is PROFILES?}

The acronym PROFILES stands for Professional Reflection Oriented Focus on Inquiry Learning and Education through Science. From such a focus, this $\mathrm{FP}_{7}$ science in society project addresses four main components, the first two directed at the teacher and the teaching, while the remaining two are more philosophical in nature:

a) P stands for Professional. This refers to ways of enhancing the teacher as a professional in addressing the concerns and issues in science education.

b) The second area of focus is indicated by ROF, or the Reflection Oriented Focus of the teacher. PROFILES recognises the need for all teachers to reflect on any intervention in which PROFILES teaching is conducted.

c) A third area of concern is the IL, or Inquiry learning. This component is heavily stressed by the EC report (2007) and thus features strongly in PROFILES.

d) The last area of focus is ES, or the need to interpret science teaching as fundamentally about educating students rather than seeing science teaching in schools as being solely focused on the fundamentals of science.

\section{What is PROFILES addressing?}

In promoting more meaningful science education, PROFILES addresses 5 major aspects, above and beyond the need to recognise inquiry-based learning (IBSE).

\section{Making Science Education Relevant}

A major factor in making science in school more popular, and expected to lead to greater public awareness of science by students in the future, is the relevance of the learning in the eyes of students (Holbrook, 2008). This relevance is clearly associated with the establishment of meaningful goals for science education (and hence education itself) but also with giving attention to addressing emerging issues in science education.

In striving for relevance in science education, PROFILES goes beyond a consideration of the educational goals and reflects on an appropriate structure related to:

- $\quad$ the manner in which the teaching is approached (Holbrook \& Rannikmäe, 2010); 
- $\quad$ enabling the teaching to be initiated from society concerns, thus allowing the learning of science to better impact on its inter-relationship with society (Holbrook \& Rannikmäe, 2007);

- $\quad$ being seen less about putting forward a series of scientific and technological conceptual topics that are, certainly at the lower levels of schooling, unrelated to the science and technology around us (Holbrook, 1998).

The rethink of science education within PROFILES requires consideration of a philosophy based on "education through science" (Holbrook \& Rannikmäe, 2007). The philosophy sees science education as firmly within the realm of education. It sees educational gains as the target of science teaching and hence the science, in its appropriate context, as the vehicle. In so doing, science education within this philosophy tries to provide students with a better awareness of science and technology within society in line with the stimulated goals of education (e.g. MCEETYA, 2008). Thus, in appreciating the philosophy associated with science education, PROFILES sees it important to distinguish between:

(i) science (a body of knowledge, or perhaps more appropriately, a way of knowing), and science education (education provided through science).

\section{Enhancing Scientific and Technological Literacy}

The "education through science" to which students strive can be referred to as education for enhancing scientific and technological literacy (STL). This literacy is far from a consideration of reading and writing and covers all the goals of education from knowledge, to skills, to attitudes, to values within a science and technology context.

In the context of relevance, it is suggested STL can be considered as meaning 'developing the ability to creatively utilise sound science knowledge (and ways of working), in everyday life, to solve problems, make decisions and hence improve the quality of life' (Holbrook \& Rannikmäe, 1997). This is based on acquiring educational skills involving intellectual, attitudinal, communicative, societal and interdisciplinary learning. It identifies with the meaning of scientific literacy put forward by PISA (OECD, 2003) "scientific literacy is the capacity to use scientific knowledge to identify questions and to draw evidence-based conclusions in order to understand and help make decisions about the natural world and the changes made to it through human activity" and also with the expanded version which goes beyond this ability and encompasses nature of science, its impact in society and a positive attitude towards this (OECD, 2007). 


\section{Context-based science education}

PROFILES sees a more society-related learning approach gaining favour with many students. PROFILES sets out to do this by involving students in constructivist learning, initiated from a familiar socio-cultural base to allow students to bridge the gap between learning within society and learning at school (van Aalsvorst, 2004). The PROFILES belief is that:

- Teaching of science in school is 'science education' and care is need when referring to the teacher's task as 'teaching science.'

- Science education is much broader than science and tries to meet the needs of students as members of society (as citizen and for careers).

- Scientific literacy has little to do with solely gaining 'the' specific scientific knowledge, whether this is expressed as content, or as 'big ideas.'

It is important to point out that an 'education through science' approach does not mean abandoning the acquiring of scientific conceptual knowledge; 'far from it.' Science provides the vehicle for learning and is thus an integral component in enabling students to gain the education goals within a suitable content frame. However, while the subject matter can be put forward by scientists and can be organised in ways that are perceived to be logical from a scientists' point of view, the same cannot be said for other educational goals.

\section{A socio-scientific teaching approach focusing on competence-based learning}

In 'Science Education Now; A Renewed Pedagogy for the Future of Europe' (EC, 2007), a major concern expressed, in relation to science teaching, is that 'science in school" is both "irrelevant" and "difficult" (p. 9). Thus, the question arises - what approach and what learning is appropriate within the field of science education to promote scientific and technological literacy? PROFILES promotes a socio-scientific approach to address motivational concerns while incorporating inquiry-based learning. PROFILES advocates a 3 stage philosophical teaching approach, controlled by the teacher, while a modular structure is put forward to present student learning tasks as one learning continuum, as well indicating teacher guidance.

\section{Student Centred Teaching}

The PROFILES teaching approach relies heavily on student involvement. And as such, there is a need to base the learning on students' prior constructs, often coming from society. A common practice is to solicit students' prior learning by means of brainstorming and from there, involve students in 
group work to develop plans for future scientific conceptual learning (investigating projects, jigsaw development of areas of learning, etc.).

\section{Operationalising profiles}

The major driving force behind the teaching of PROFILES relates to (a) the theoretical model and (b) the design of PROFILES modules.

\section{The 3 stage model}

The 3-stage model is based on the recognition that there is a need to initiate the learning from a familiar and student relevant situation. The diagram below illustrates how relevance is intended to trigger student's self-motivation (or intrinsic motivation) to promote student involvement in the learning. Such motivation is sustained by student involvement and also by any extrinsic motivational aspects supplied by the teacher.

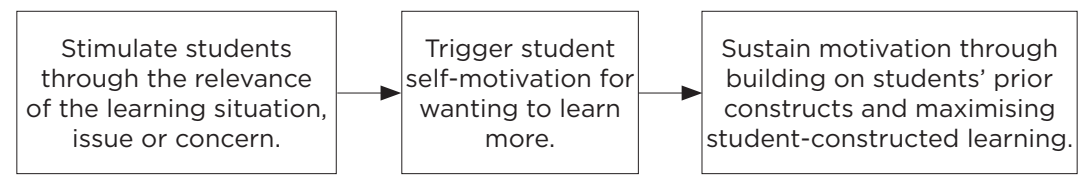

As the model is the centrepiece of the PROFILES approach it is elaborated further.

\section{The Stage 1 Scenario}

The use of an 'appropriate' scenario is important. Not any situation is appropriate. Research shows that students identify with specific words, or expressions and these play an important function in determining whether the modules, or the scenario, chosen is appropriate. So important is the title and scenario that, if this fails to motivation students, the module should not be used further and the teaching associated with this module abandoned. This is because relevance is a very useful precursor for developing students' personal interest and a powerful stimulus for science learning. It provides students with a desire to pursue the learning further, going beyond the scenario and into the accompanying new science learning.

The learning approach is thus 'motivation first', leading to science learning second. This contrast with the usual suggested approach - make the science itself interesting so that it will then motivate the students (but, alas, in so many cases it doesn't!!). The theoretical construct is that motivation drives the learning of science and the scenario is intended to enable students to want to get 
involved, even though this means learning some science. Unfortunately, standard approaches, which assume science is inherently interesting for students, if taught well, have been shown not to appeal to many students at the secondary level (Osborne et al., 2003).

Once motivation is established, the further learning is, in fact, the curriculum-based conceptual science ideas, which students acquire as steps towards enhancing their scientific literacy. For the learning to be meaningful as well as continue to be interesting, the science learning builds on a familiar, socio-scientific scenario as shown in the flowchart.

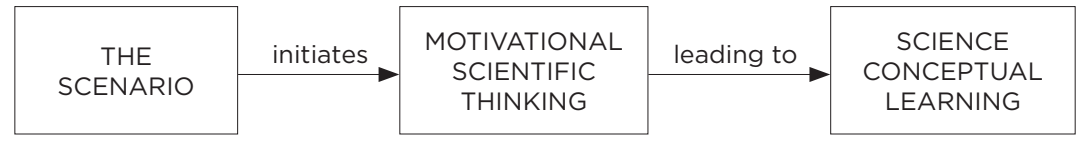

The purpose of the scenario is to stimulate students' interest and to do this from a familiar and student relevant perspective. It is thus importance to persuade teachers to make changes to the scenario, if appropriate, to ensure such an approach.

Starting from a carefully worded title (intended to be familiar and of interest to the target students), the teaching progresses, in three stages via a scenario, as follows:

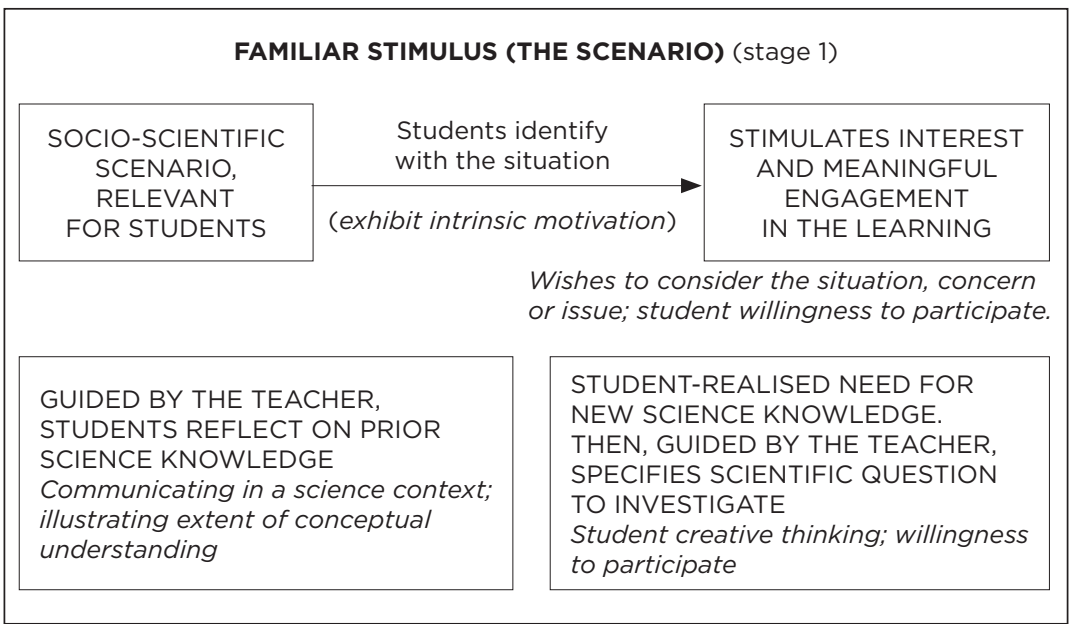




\section{INQUIRY-BASED SCIENCE EDUCATION (stage 2)}

EXPLORES SCIENTIFIC QUESTION 1 Student constructed, creative thinking, showing - initiative, conceptual understanding, perseverance, planning ability

EXPLORES SCIENTIFIC QUESTION 2,3 etc. (if appropriate) Creative thinking, initiative, conceptual understanding, perseverance
PROBLEM SOLVING INVESTIGATION Exhibits process skills, creative thinking, cognitive reasoning, collaboration with others, leadership qualities, safe working

PROBLEM SOLVING INVESTIGATION Process skills, creative thinking, communication, leadership, cognitive reasoning, collaboration with others

CONCEPTUAL SCIENCE LEARNING

(LEADING TO CONCEPT MAP FORMATION;

RELATING NEW AND OLD SCIENCE CONCEPTS)

\section{SCIENCE CONSOLIDATION AND SOCIO-SCIENTIFIC DECISION MAKING (stage 3)}

REFLECTION ON/CONSOLIDATION OF NEW SCIENCE KNOWLEDGE GAINED

Conceptualisation, independent thinking, student constructed modelling, communicating

Cognitve thinking
SOCIO-SCIENTIFIC DECISION

MAKING

Within the socio-scientific context (the scenario), argumentation, reasoning for making socio-scientific decisions, independent thinking, social values, tolerance of views of others, leadership

\section{Going beyond the scenario}

Once teacher realise the need to initiate motivational scientific thinking in their students, the next step is to determine students' prior science knowledge in the area related to the socio-scientific scenario.

In most cases, the teacher should expect to find that the students' prior knowledge is limited and students will be unfamiliar with the science ideas associated with the scenario. However, if this is not the case and students really do have a background in the underlying science, then going further to discuss the scenario will not involve science learning. The teaching needs to re-focus so as to be seen to address learning.

\section{Preparing for stage 2}

While stage 1 is initially about raising student interest, stage 2 is the important stage for the learning of new conceptual science. Experience has shown (PARSEL project) that teachers need to be guided to appreciate how to move from stage 1 and into stage 2 . The expected steps (considered within stage 1 ) are to: 
(a) enable students to recognise that they can discuss little about the scenario without learning the underlying science ideas, and then;

(b) develop the scientific question(s) (by the students if possible, otherwise by the teacher guiding the students - trying hard to not tell), which are to be answered within stage 2 .

Moving from the scenario to developing the scientific question is heavily dependent on the skill of the teacher. Collective teacher discussions, after teachers have tried out a module, can give strong consideration to the ways teachers have handled this component.

\section{Undertaking stage 2}

This is likely to be the stage where most of the module's teaching/learning time is spent and where students gain conceptually and also at a personal and social educational level (education through science). The approach here is one of maximising student-constructed learning (inquiry-learning or IBSE) and that the pace of teaching will depend heavily on students' skills, developed on prior occasions.

If students have much prior experience in carrying out process skills, then undertaking evidence-gathering learning (a key element within a scientific approach) will be much facilitated. IBSE can be expected to take far less time than in cases where students have not had prior opportunities for studentcentred learning. There is a need to stress the importance of the evidence gathering aspects, whether by experimentation, or by other means.

\section{Explaining inquiry learning}

Teachers must have a clear notion of the intentions behind inquiry learning. This understanding must go beyond student attainment of manipulative process skills. The inquiry learning is intended to be student-constructed learning, with the teacher as facilitator. It is definitely NOT simply following a worksheet and recording a given answer.

The following are all very much part of IBSE (although not actually seen as process skills):

- $\quad$ identifying the science in a socio-scientific situation;

- $\quad$ putting forward scientific questions (questions that can be investigated scientifically);

- $\quad$ if necessary, breaking down questions into sub-questions that can be investigated separately.

Also, students can be expected to learn to use communication skills to 
present their conclusions in suitable ways (written, oral, ICT) and, as appropriate, discuss the limitations associated with the solutions they reach in attempting to solve the problem (answers to the questions). Furthermore, inquiry learning is also very much interrelated with the development of social skills, especially interpersonal (student-student and student-teacher) developments and also personal skills, associated with aptitudes that support inquiry learning such as initiative, ingenuity, safe-working and perseverance.

\section{Different degrees of student-constructed learning (within IBSE)}

Although elements of IBSE are given above, teachers can undertake inquiry learning with their students in different ways. The ultimate goal is to enable students to undertake inquiry learning with no, or minimum, teacher interference (i.e. students undertake project work or 'open' inquiry). For that teachers will need to teach students to construct their thinking for the different stages of inquiry learning. And teachers must realise that the more practice students have in IBSE, the more easily and the more capable they will be in undertaking high levels of student-constructed IBSE. An example of the various stages (and sub-stages) that teachers can consider in planning specific IBSE experiences for students is illustrated by Smith (2011), who in turn modified that by Herron (1971), where 'given' means 'supplied by the teacher' and 'open' means 'supplied by the students.'

\begin{tabular}{|c|c|c|c|c|}
\hline $\begin{array}{l}\text { Level of } \\
\text { Inquiry }\end{array}$ & $\begin{array}{l}\text { Scientific } \\
\text { Problem }\end{array}$ & $\begin{array}{l}\text { Material/ } \\
\text { Equipment }\end{array}$ & $\begin{array}{l}\text { Planning/ } \\
\text { Procedure }\end{array}$ & $\begin{array}{l}\text { Answer/ } \\
\text { Solution }\end{array}$ \\
\hline $0^{*}$ & Given & Given & Given & Given \\
\hline 1 Structured & Given & Given & Given & Open \\
\hline $\begin{array}{l}2 \text { Guided } \\
\text { (option A) }\end{array}$ & Given & $\begin{array}{l}\text { Given (totally or } \\
\text { maybe partly) }\end{array}$ & Given (totally or maybe partly) & Open \\
\hline $\begin{array}{l}2 \text { Guided } \\
\text { (option B) }\end{array}$ & Given & Open & Open & Open \\
\hline $\begin{array}{l}2 \text { Guided } \\
\text { (option C) }\end{array}$ & Given & $\begin{array}{l}\text { Partially given (by } \\
\text { providing a range of } \\
\text { material that includes } \\
\text { - as a subset - what is } \\
\text { required). }\end{array}$ & $\begin{array}{l}\text { Open from pupils' perspec- } \\
\text { tive (but given by teachers as } \\
\text { the need to use materials as } \\
\text { provided). }\end{array}$ & Open \\
\hline $\begin{array}{l}2 \text { Guided } \\
\text { (option D) }\end{array}$ & $\begin{array}{l}\text { Par- } \\
\text { tially open } \\
\text { (given as } \\
\text { broad pa- } \\
\text { rameters) }\end{array}$ & Open & $\begin{array}{l}\text { Partially given (e.g. through } \\
\text { previous experience of control- } \\
\text { ling variables, analogy with other } \\
\text { experiments or forms of investi- } \\
\text { gation, but open in the sense of } \\
\text { not being told what to do). }\end{array}$ & Open \\
\hline $\begin{array}{l}2 \text { Guided } \\
\text { (option E) }\end{array}$ & Open & $\begin{array}{l}\text { Partially open (this is } \\
\text { what we have in the } \\
\text { school) }\end{array}$ & $\begin{array}{l}\text { Open (but teacher needs to } \\
\text { be careful to check on safety } \\
\text { aspects) }\end{array}$ & Open \\
\hline 3 Open & Open & Open & Open & Open \\
\hline
\end{tabular}


Teachers need to recognise that progression through the approaches given in the paragraph above is NOT expected to be LINEAR. Thus the types within 2 and type 3 (open inquiry) will all depend on the module being promoted.

\section{Preparing for stage 3}

The solution to the scientific question, carefully detailed and recorded, is expected to be the gateway to stage 3 . In stage 3 , the science gained from the inquiry learning in stage 2 can be used to further consider the socio-scientific issue that was initiated in stage 1. A good approach for consolidating this science is to construct a concept map.

\section{Creating concept maps}

Stage 2 incorporates conceptual science learning. It brings in new science. To be useful, this science needs to be put into a scientific context and, in particular, interrelated with other science knowledge. Novak and Gowin (1984) have shown that scientific concepts can be interlinked by means of a concept map, based on a theoretical construct (Novak \& Cañas, 2006). Compiling concept maps can be a useful assessment exercise in which students can illustrate their learning of scientific patterns - a valuable aspect in developing the science ideas further.

The width of the science teaching identified and promoted by the teacher (the range of scientific concepts) will depend on factors such as:

- $\quad$ the teacher's interest;

- $\quad$ the ability of the students;

- $\quad$ the level of interest which can be sustained by students, and, of course;

- $\quad$ external factors such as teaching time available.

An Example of a possible concept map for a PROFILES module related to Biodiesel

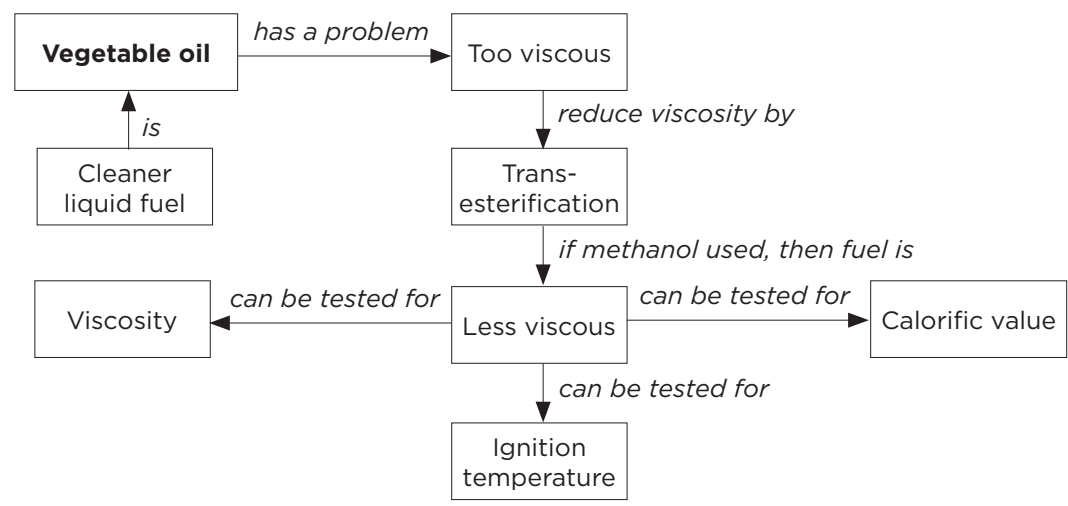


The module does not need to cover the conceptual science as per that indicated in the curriculum arrangement (or the textbook). A teacher always has the prerogative to determine the sequence (the curriculum should match the students; not the students struggling to match the curriculum!).

\section{Undertaking stage 3}

Stage 3 has two major components:

(a) To consolidate the science ideas introduced in stage 2. This is achieved by involving students in additional tasks (above and beyond the module) related to the concepts, preferable interlinking with the students' prior concepts which were identified in stage 1 . These tasks may be presented in different formats e.g. oral discussions; answering written exercises; jigsaw method, etc.

(b) Utilise the science ideas gained, transferred to the original scenario situation, so as to enable students to discuss the scenario situation in more detail, using the newly acquired science. This is an important component of the learning and is expected to achieve two major learning targets (i) being able to transfer scientific ideas to a new, contextual situation, and (ii) participate meaningfully in a decision-making exercise to arrive at a justified decision related to the initial socio-scientific situation outlined in the title of the module.

Part (b) will involve student groups, or whole class interactions, in activities such as debates, role playing, or discussions. Students are expected to put forward their points of view, the teacher ensuring they incorporate the new science in a meaningful and appropriately correct manner. Students are thus involved in aspects of argumentation, as well as communicating the new science ideas in a conceptually correct manner. The end result is a set of small group decisions, or a consensus decision made by the class as a whole. The actual decision is not, in itself, as important as the justifications put forward, but would be expected to comply with social values accepted by the local society as a whole.

\section{PROFILES Modules}

The teaching approach is very much guided by the modules and the thrust is very much associated with the philosophy: from familiar to unfamiliar; social to scientific, social relevance to scientific conceptualisation. Student attitudes are thus of much importance and ensuring teachers do identify that motivation is being promoted and prolonged is a key component.

Modules do not explicitly indicate the various stages, often so as not to 
convey to teachers and students that the learning is intended to be compartmentalised. Students are not expected to be aware of the 3 stages.

\section{Structure of the modules}

While the structure of these modules is not to be taken as an absolute, the following components are seen as important for the general approach to the development of modules: a frontpage; student activities or tasks; teacher's guide; assessment; background teacher notes (in science and pedagogy). They are further elaborated to appreciate their value and guide teachers in how best to make appropriate use of modules. Each component is described in turn. The following sub-sections explain further the structure of the modules as they actually appear.

\section{The Frontpage}

This is a double sided cover, attractively laid out to draw attention to the module title, a summary of the science content, as well as elaboration of the 'education through science' learning portrayed in the form of competences to be developed through the teaching using the module. The competences are important as they indicate the intended learning and hence the components that are to be assessed during the learning. As they are related to 'education through science, the competences go beyond knowledge and encompass skills, attitudes and value, relevant to the situation and the intended learning.

\section{Student activities}

In setting out the student activities, it is important to realise that this section is designed for the students. It directly involves the students in constructing their learning. Yet at the same time, it is not intended to take over from the teacher and dictate to the teacher how this aspect should be undertaken. With the recognition that the teacher needs to determine how the teaching should be conducted, the student activities as a single set and are not divided between the 3 stages, although the scenario is given. Also, although the student activities are listed, they are usually not explicitly supported by worksheets (worksheets, if provided, are purposely included in the teacher notes so that the teacher has the option of deciding whether they are appropriate for use or not).

\section{Teacher's guide}

Teachers need to recognise this as an important section in the module. It sets out to guide the teacher in appreciating the situation put forward by the designers of the module and the manner in which they intend the learning to develop. Nevertheless, the guidance given is advisory and it is expected that it can 
be overridden by the teacher, as and when the teacher feels appropriate. Clearly the indicated freedom for the teacher is important, as the intention is to utilise 'relevance to the students' as a motivational factor and also to develop the learning in a constructivist fashion, based on the students' actual prior knowledge.

\section{Assessment}

In an 'education through science' setting, not all competences can be determined by using a pencil and paper assessment strategy. Furthermore, in new situations, it is valuable to determine and support student progress. This lends itself to formative assessment strategies and hence this section is intended to guide the teacher to develop this area. Once again, however, the suggestions are for guidance to suit the circumstances and not for the teacher to follow without modification. It is noteworthy that teachers had difficulty with formative assessment ideas during the PARSEL project (www.parsel.eu) and this aspect may need to be introduced to teachers slowly over much time and teachers being permitted to discuss among themselves at length.

\section{Teacher notes}

This section, which may or may not be present, is for additional supporting material that can be offered to the teacher to assist the teaching. Noting the inter-disciplinarity of modules, this section can provide notes on the wider science content which may be unfamiliar to the teacher, suggested worksheets for students, provide answers to questions raised in the student activities, or detail experimental and safety aspects.

\section{Conclusion}

PROFILES is an ongoing project. The impact of the project so far, in promoting innovative teaching and the incorporation of the PROFILES ideas, is illustrated in the following articles and in other publications (Bolte, Holbrook, Mamlok-Naaman, \& Rauch, 2014; Bolte, Holbrook, \& Rauch, 2012; Special issue of Science Education International - accessed on www.icaseonline.net/seiweb). Access to PROFILES modules is via the project website www.profiles-project.eu, or the local websites of the partners.

\section{References}


Order Thinking Across the Disciplines. The Curriculum Reform Project, University of Colorado, USA.

Bolte, C., Holbrook, J., Mamlok-Naaman, R., \& Rauch, F. (Eds.) (in press). Science Teachers

Continuous Professional Development in Europe. Case Studies from the PROFILES Project. University of Klagenfurt.

Bolte, C., Holbrook, J., \& Rauch, F. (Eds.) (2012). Inquiry-based Science Education in Europe: First

Examples and Reflections from the PROFILES project. University of Klagenfurt.

European Commission (EC). (2007). Science Education Now: A renewed pedagogy for the Future of

Europe. Brussels: European Commission.

European Commission (EC). (2004). Europe needs more scientists. Report of a High Level

Commission. Brussels: European Commission.

Feinstein, N. (2010). Salvaging science literacy. Science Education, 95(1), 168-185.

Fernandez, C., Holbrook, J., Mamlok-Naaman, R., \& Coll, R. K. (2013). How to teach science in emerging and developing environments. In I. Eilks \& A. Hofstein (Eds.), Teaching Chenistry - A

Studybook. Rotterdam, The Netherlands: Sense Publishers.

Froiland, J. M., \& Oros, E. (online published 2013). Intrinsic motivation, perceived competence and classroom engagement and longitudinal predictors of adolescent reading achievement. Educational Psychology, 1-14.

Griffin, P., Care, E., \& McGaw, B. (2012). The Changing Role of Education and Schools. In P. Griffin, B. McGaw, \& E. Care (Eds.), Assessment and Teaching of 21st Century Skills (pp. 1-45). London: Springer.

Herron, M. D. (1971). The nature of scientific enquiry. School Review, 79(2), 171-212.

Hofstein, A., Eilks, I., \& Bybee, R. (2011). Societal issues and their importance for contemporary science education: a pedagogical justification and the state of the art in Israel, Germany and the USA. International Journal of Science and Mathematics Education, 9(6), 1459-1483.

Holbrook, J. (1998). Operationalising Scientific and Technological Literacy - A New Approach to Science Teaching. Science Education International, 9(2), 13-19.

Holbrook, J. (2008). Introduction to the Special Issue of Science Education International devoted to PARSEL. Science Education International, 19(3), 257-266.

Holbrook, J. (2010). Education through science as a motivational innovation for science education for all. Science Education International, 21(2), 80-91.

Holbrook, J. B. (1992). Teaching Science the STS way. In R. E. Yager (Ed.), The Status of Science-

Technology-Society Reform Efforts around the World: ICASE 1992 Yearbook. Hong Kong: ICASE. Holbrook, J., \& Rannikmäe, M. (Eds.) (1997). Supplementary teaching materials promoting scientific and technological literacy. Tartu, Estonia: ICASE (International Council of Associations for Science Education).

Holbrook, J., \& Rannikmäe, M. (2007). The Nature of Science Education for Enhancing Scientific Literacy. International Journal of Science Education, 29(11), 1347-1362.

Holbrook, J., \& Rannikmäe, M. (2009). The Meaning of Scientific Literacy. International Journal of Environmental and Science Education, 4(3) 275-288. 
Holbrook, J., \& Rannikmäe, M. (2010). Contextualisation, de-contextualisation, re-contextualisation - A science teaching approach to enhance meaningful learning for scientific literacy. In I. Eilks \& B. Ralle (Eds.), Contemporary Science Education (pp. 69-82). Aachen, Germany: Shaker.

Krajcik, J., Mamlok, R., \& Hug, B. (2001). Modern Content and the Enterprise of Science: Science Education for the Twentieth Century. In L. Corno (Ed.), Education Across A Century: The Centennial Volume. One Hundredth Yearbook of the National Society for the Study of Education (pp. 205-237). Lemke, J. (2005). Research for the future of science education: New ways of learning, new ways of living. Plenary presented at the VIIth International Congress on Research in Science Teaching. Granada, Spain. Retrieved November 2010 from http://www-personal.umich.edu/ jaylemke Levy, F., \& Murnane, R. J. (2005). The new division of labor: How computers are creating the next job market. Princeton, NJ: Princeton University Press.

Ministerial Council on Education, Employment, Training and Youth Affairs (MCEETYA). (2008). Melbourne Declaration on Educational Goals for Young Australians. Retrieved December 2010 from www.mceetya.edu.au

Novak, J. D., \& Cañas, A. J. (2006). The Theory Underlying Concept Maps and How to Construct Them. Technical Report No. IHMC CmapTools 2006-01. Pensacola, FL: Institute for Human and Machine Cognition.

Novak, J. D., \& Gowin, D. B. (1984). Learning How to Learn. New York: Cambridge University Press. National Research Council (NRC). (2010). Exploring the Intersection of Science Education and 21st Century Skills: A Workshop Summary. Margaret Hilton, Rapporteur. Board on Science Education, Center for Education, Division of Behavioral and Social Sciences and Education. Washington, DC: The National Academies Press.

Organisation for Economic Cooperation and Development (OECD). (2003). The PISA 2003 assessment framework. Retrieved November 2008 from http://www.pisa.oecd.org/ dataoecd/46/14/33694881.pdf

Organisation for Economic Cooperation and Development (OECD). (2007). Assessing Scientific, Reading and Mathematical literacy: A framework for PISA 2006. Retrieved from http://www.oecd.org/ dataoecd/63/35/37464175.pdf

Osborne, J., \& Collins, S. (2001). Pupil's views of the role and value of the science curriculum: a focus-group study. International Journal of Science Education, 23(5), 441-467.

Osborne, J., Simon, S., \& Collins, S. (2003). Attitudes towards science: a review of the literature and its implications. International Journal of Science Education, 25(9), 1049-1079.

Rannikmäe, M. (2001). Guiding teacher development towards STL teaching: identifying factors affecting change. Science Education International, 12(3), 21-27.

Roberts, D. A. (2007). Scientific literacy / science literacy. In S. K. Abell \& N. G. Lederman (Eds.), Handbook of research on science education (pp. 729-780). Mahwah, NJ: Lawrence Erlbaum Associates. Ryan, R. M., \& Deci, E. L. (200o). Self-determination theory and the facilitation of intrinsic motivation, social development and well-being. American Psychologist, 55, 68-78. Sjoberg, S. (2001). ROSE: The relevance of science education. A comparative and cooperative 
international study of the contents and contexts of science education. Retrieved http://folk.uio.no/ sveinsj/ROSE_files.htm

Sjöström, J. (2011). Towards Bildung-oriented chemistry education. Science \& Education, online. Retrieved doi 10.1007/s11191-011-9401-0.

Smith, C. (2011). Scientific Thinking. ICASE newsletter April 2011. Retrieved online www.icaseonline. net/news.html

Teppo, M., \& Rannikmäe, M. (2008). Paradigm Shift for Teachers: More Relevant Science Teaching. In J. Holbrook, M. Rannikmäe, P. Reiska, \& P. Ilsley (Eds.), The Need for a Paradigm Shift in Science Education for Post-Soviet Societies (pp. 25-46). Germany: Peter Lang Verlag.

Turner, R. S. (2008). Why we teach school science, and why knowing why matters. Keynote Address to the CRYSTAL Atlantique Annual Colloquium, Fredericton, New Brunswick, Canada.

Tytler, R. (2007). Australian education review: Re-imagining science education engaging students in science for Australia's future. Victoria: ACER Press.

UNESCO. (1999). World Conference on Science: Framework for Action. Paragraph 71. Paris: UNESCO. Van Aalsvoort, J. (2004). Logical positivism as a tool to analyse the problem of chemistry's lack of relevance in secondary school chemical education. International Journal of Science Education, 26(9), $1151-1168$

Zoller, U. (1993). Are lecture and learning compatible? Maybe for LOCS: unlikely for HOCS. Journal of Chemical Education, 70, 195-197.

\section{Biographical note}

JaCK Holbrook, visiting professor in science education at the University of Tartu, was educated in the UK and obtained a $\mathrm{PhD}$ in Chemistry from the University of London. He was a secondary school science teacher before moving into teacher education in various countries. He is also a freelance international consultant in science education, curriculum and assessment. He is a past president of ICASE (international council of associations for science education), journal editor and chair of the international projects committee. Jack is a major instigator in developing the PROFILES project ideas.

Mita RANnikmäE is professor and chair of the Centre of Science Education, University of Tartu, Estonia. She teaches science education at the M.Ed and $\mathrm{PhD}$ levels and runs a number of research projects. She has published extensively in science education journals, particularly in the field of scientific and technological literacy. Miia is chair of the University liaison committee for ICASE and an active member of the local chemistry teachers association. She is a workpackage leader for the European Commission, $\mathrm{FP}_{7}$ PROFILES project. 